\title{
The Failure Of Collective Security In The Post World Wars I And II International System
}

\author{
Joseph C. Ebegbulem \\ University of Calabar, Nigeria
}

\section{Introduction}

World War I pointed out a fundamental flaw in the balance of power system. When the system failed, the result was dangerous and catastrophic. The incredible levels of destruction in the war led most nation-states to reject a balance of power system as the basis for international security in the post-World War I. Instead, the victorious states sought to institutionalize a system of collective security via the League of Nations in which aggression by one state would bring response from all states; collective security would thus be achieved.

The achievement of this "collective security" would be based on the principle that an attack on one is an attack on all. Any state contemplating aggression would face the sure prospect of struggle not simply with the prospective victim, but with all other members of the system, who would make any necessary sacrifice to save the state attacked. In a hypothetical world of collective security, the assumption is that the members of the system will have such an overwhelming preponderance of power that will be so unreservedly committed to the principles they have endorsed that aggression will become quite irrational; presumably, it will not occur or if it should occur, it will be defeated. The League of Nations and the United Nations are two post-World War (first and second World Wars) agencies under which the collective security system has been used as machinery for joint action for the prevention or counter of any attack against an established international order.

The objective of collective security is to frustrate any attempt by states to change the status quo with overwhelming force because a change in the status quo entails a change to the world order of independent sovereign states. This was meant to muster overpowering collective force, which could threaten and then applied to end aggression by revisionist states and other would-be aggressors. 


\section{Meaning And Nature Of Collective Security}

According to George Schwarzeberger, collective security is a "machinery for joint action in order to prevent or counter any attack against an established international order" (schwarzenberger, 1951).The term implies collective measures for dealing with threat to peace.

Van Dyke (1957) sees collective security as a system in which a number of states are bound to engage in collective efforts on behalf of each other's individual security. To A. K. Chaturvedi (2006), collective security is "an arrangement arrived at by some nations to protect their vital interests, safety or integrity, against a probable threat or menace over a particular period, by means of combining their powers."

In his conceptual clarification, Onyemaechi Eke (2007) sees the concept of collective security as "an idealist one which hinges on the prevention of hostilities by the formation of an overwhelming military force by member states to deter aggression or, by implication, to launch a reprisal attack capable of defeating the recalcitrant member." According to him, collective security "connotes the institutionalization of a global police force against abuse of order and breaches, which can lead to insecurity. It is an arrangement in which all states cooperate collectively to provide security for all by the actions of all against any state within the groups which might challenge the existing order by using force. By employing a system of collective security, the United Nations hopes to dissuade any member state from acting in a manner likely to threaten peace, thereby avoiding conflict.

From the above definitions by these eminent scholars, collective security can then be seen as a plan for maintaining peace through an organization of sovereign states, whose members pledge themselves to defend each other against attack. The concept is best seen as "security for individual nation by collective means", that is, by membership in an international organization made up of all or most of the states of the world pledged to defend each other from attack. The idea of collective security was extensively discussed during the World War I, and it took shape in the 1919 Covenant of the League of Nations, and again in the Charter of the United Nations after Word War II.

According to Palmer and Perkings (2007), "a collective security system, to be effective, must be strong enough to cope with aggression from any power or combination of powers, and it must be invoked if and as aggression occurs." The principle of collective security involves a willingness to apply sanctions as and when necessary and even to go to war. Collective security will never work unless all the nations that take part in it are prepared simultaneously to threaten with 
sanctions and to fight, if necessary, an aggressor. It must be open to those states which are willing to accept its obligations in good faith.

Rourke and Boyer (1998) assert that collective security is based on four principles: first, all countries forswear the use of force except in self defence; second, all agree that peace is indivisible, an attack on one is an attack on all; third, all pledge to unite to halt aggression and restore the peace; fourth, all agree to supply whatever material or personnel resources that are necessary to form a collective security force associated with the United Nations or some IGO to defeat aggressors and restore the peace.

The principle of collective security is found in Article 48 and 49 of the Charter of the United Nations which states that, "the action required to carry out the decisions of the Security Council for the maintenance of international peace and security shall be taken by all the members of the United Nations or by some of them, as the Security Council may determine; such decisions shall be carried out by the members of the United Nations directly or through their action in the appropriate international agencies of which they are members."

The idea behind the collective security system is that members of the organization advancing the collective security system (this time, the United Nations) are bound to spring to each other's defense in case of attack. The basic principle is that an attack on one is an attack on all. Any state contemplating aggression would face the sure prospect of struggle not simply with the prospective victim, but with all other members of the system, who would make any necessary sacrifice to save the state attacked.

"In a hypothetical world of collective security, the assumption is that the members of the system will have such an overwhelming preponderance of power and will be so unreservedly committed to the principles they have endorsed that aggression will become quite irrational; presumably, it will thus not occur, or if it should occur, it will be defeated." (Dyke, 1957)

\section{Problems Of Collective Security}

At the twilight of World War I, many political thinkers thought and hoped that the states of the world would make the League of Nations a collective security system that would maintain international peace and security, and some had the same hope after World War II in connection with the United Nations. Karen Mingst averred that collective security is borne out of some salient assumptions. These 
assumptions are that: wars are prevented by restraint of military action; aggressors must be stopped; the aggressor is easily identified; the aggressor is always wrong; aggressors know that the international community will act against them (Mingst, 1999). As asserted by Van Dyke (1957), "they wanted states to abandon narrow conceptions of self interest as a guide to policy and to regard themselves as units in a world society having an interest in preserving law and order everywhere." These ideas expressed by these scholars could not work out as a result of numerous problems associated with the concept of collective security. There are other scholars who feel that the concept of collective security is misguided. They see it as conceptually muddled and naively unrealistic. Although they are pledged to defend each other, many countries will refuse to do so, if such an act is not in their own best interests or thought to be too risky or expensive. In addition, they argue that collective security arrangements will turn small struggles into large ones, and prevent the use of alternative (non-violent) problem solving, relying instead on the much more costly approach of military confrontation. In addition, there is always a danger that alliances formed by the purpose of collective security can also serve as a basis for an aggressive coalition. Other problems associated with the collective security system are discussed as follows:

(i) States do not regard themselves as members of one society having a common vital interest in protecting and preserving each other's rights. Does it really matter to Japan if Paraguay and Bolivia destroy themselves in a war? Of what interest is it to Nigeria if Egypt should attack Tunisia and such attack is repelled or defeated? There is no doubt that states have demonstrated a willingness to ally themselves with certain other selected states and thus to pledge to defend certain selected frontiers in addition to their own, but the principle of "one for all and all for one" does not commend itself.

(ii) Another challenge to collective security is that its risks are great. Governments of nation-states can enforce law against individuals with little risk or fear. Internationally, however, the situation is quite different. Disparities of power are much greater. "Theoretically, it might be easy for a world society to defeat aggression by a smaller power like Nigeria, but what if one of the great powers turns aggressor?" it is one thing for a government to enforce a law against a hapless individual and another thing for the United Nations to try to enforce the law against a state which may be almost as strong as the rest of the world combined. The development of nuclear weapons makes the problem all the greater. An aggressor with such weapons could virtually wipe from the face of the earth a number of the members of the collective security system. Faced with such a possibility, a member whose own most vital interest was directly threatened might choose proud defiance rather than surrender. But a member whose own vital interests were not directly 
threatened would be unlikely to be so bold. Nor do states want to commit themselves in advance to undertake such risks, regardless of the identity of the aggressor and of his victim.

(iii) Jones (1985) and Rostow (1968) cited in Eke (2007) are in agreement that the principles of the United Nations veto is "a great inhibition to the smooth and effective functioning of the Security Council collective security system. In his observation, Rostow argued that "part of the problem is that the responsibility of world peace was resting on the shoulders of nations with preponderant military and political power." By this, he meant those nations that could become arrogant to ignore local wars, revolutions, or conquests on the assumption that they do not disturb the general equilibrium of power or endanger the sense of security of the system as a whole.

The veto principle of the Security Council of the United Nations was originally meant to ensure commitment of the five permanent members to the United Nations. It was also meant that no superpower is against any UN action, which can lead to outbreak of hostilities (Butler, 1999). The superpowers were expected to exercise collective responsibility for the maintenance of global peace and security. But what we see today has been unilateral actions by some permanent members of the Security Council with veto powers, especially the United States and Great Britain against countries they perceive as threats to international peace and security. A good example is the invasion of Iraq by the United States and Britain, "this wave of American-styled security by domination in place of collective security creates both anxiety and curiosity over the weakness of the United Nations Collective Security as "sine qua non" for world peace and security.

(iv) The activities of powerful regional organizations have posed a serious problem to United Nations Collective Security System. "Experience has shown that members of such organizations demonstrate divided loyalty often times with more concern to the regional organization than the UN." (Eke, 2007) Members of regional security have often abandoned the UN Collective Security System in preference to regional security system. Bulter observed that during the invasion of Iraq by the United States "the Security Council - the hub of collective security regime was bypassed, defied and abused..." (Butler, 1999). Palmer and Perkings agree that the United States and western powers, in their attitudes of placing more emphasis on national and regional defence than on collective security as the obligation to the Charter of the United Nations are fundamental problems of unanimity of the Council and by extension, the cause of failure of security regime. (Palmer and Perkins, 2007) 
In many instances of states and regional conflicts, members of regional security abandon the UN. For example, the North Atlantic Treaty Organization (NATO) had helped to bury the optimism, which greeted the UN Collective Security System in the 78-day bombing of Yugoslavia, and of course Iraq, after the fall of Soviet empire. In these two crises situation, the Security Council which is the hub of collective security regime was bypassed. The double allegiance of members of the United Nations, especially by the veto-wielding ones, concretely depicts moral failure.

\section{Failure Of Collective Security Under The League Of Nations}

Palmer and Perkings observed that the League of Nations was a complete failure as an instrument for enforcement of collective security. They cited the failure of the United States of America to join the League from the start and the rise of the Soviet Union outside the League as one of the major reasons why the League failed as instrument for the development and enforcement of collective security. They also believed that "the open defiance of Japan, Italy and Germany combined to destroy any hopes that the League would be effective in major international crisis." (Palmer and Perkings, 2007) This line of thought was also captured by Charles, Kegley. He posits that "the failure stemmed from the U.S. refusal to join the organization; the other great powers' fear that the League's collective strength might be used against them. (Kegley, 2007)

Another example of the failure of the League of Nations' collective security is the Manchurian crisis when Japan occupied part of China. After the invasion, members of the League passed a resolution calling for Japan to withdraw or face severe penalties. Given that every nation on the League of Nations Council had veto power, Japan promptly vetoed the resolution, severely limiting the League of Nations' ability to respond. After two years of deliberation, the League passed a resolution condemning the invasion without committing the League's members to any action against it. The Japanese replied by quitting the League of Nations.

A similar process occurred in 1935, when Italy invaded Ethiopia. Sanctions were passed, but Italy would have vetoed any stronger resolution. Additionally, Britain and France sought to court Italy's government as a potential deterrent to Hitler, given that Mussolini was not in what would become the Axis Alliance of World War II. Thus, neither enforced any serious sanctions against the Italian government. 
Karen Mingst argued that Collective Security does not always work. She observed that the inability of the international community to respond to Japan's invasion of Manchuria and Italy's assault on Ethiopia was the fundamental differences in state interests and ideologies. According to her, "Collective Security does not always work. In the period between the two world wars, Japan invaded Manchuria and Italy overran Ethiopia. In neither case did other states act as if it were in their collective interest to respond.... In this instance, collective security did not work because of lack of commitment on the part of other states and an unwillingness of the International Community to act in concert. In the post-World War II era, Collective Security could not work because of fundamental differences in both state interests and ideologies." (Mingst, 1999)

Additionally, in this case and with the Japanese invasion of Manchuria, the absence of the USA from the League of Nations deprived the League of another major power that could have used economic leverage against either of the aggressors states. Inaction by the League subjected it to criticisms that it was weak and concerned more with European issues (most leading members were Europeans) and did not deter Hitler from his plans to dominate Europe.

\section{Failure Of Collective Security Under The United Nations}

While Article I of the UN Charter calls for "effective collective measures for the prevention and removal of threats to the peace, and for the suppression of acts of aggression or other breaches of peace," Article 43 of the Charter provides that members of the UN, in accordance with special agreements to be conducted, are to make available to the Security Council "armed forces, assistance and facilities, including rights of passage, necessary for the purpose of maintaining international peace and security." These shall take place "if the Security Council finds that an act of aggression or other threats to the peace has occurred, and if the parties concerned do not comply with such measures as the Council shall deem necessary..." (Palmer and Perkings, 2007)

The United Nations calls for necessary measures to maintain international peace and security, including the obligation of states to place at the disposal of the United Nations agreed power necessary for an international peace force to be equipped with agreed types of armaments. Rather than have an institutionalized collective security regime, under the U.N. regularized training, maintenance and command, loosely Collective Security mechanism took the force of multinational willingness to control troops to promote the U.N. peace agenda. Where there exists an aggressor, there is need to collectively counter the attacks of the aggressor and 
preserve the peace through a Collective Security system. In such a situation no member state of the United Nations can claim neutrality, and none would dare to support the aggressor. If the aggressor dares to use force, then the combined forces of all the other states should so overwhelm the aggressor that hostilities would terminate and would cause would-be aggressor to retrace its steps for fear of sanction.

One of the problems of the United Nations Collective Security system is the unwillingness of countries to subordinate their sovereign interests to collective action. "Thus far, governments have generally maintained their right to view conflict in terms of their national interest and to support or oppose UN action based on their nationalistic point of view. Collective Security therefore exists mostly as a goal, not as a general practice.” (Rourke and Boyer, 1998)

Another problem which have resulted in the failure of the United Nations Collective Security system is the overdependence of the Security Council on the member-governments for assistance, especially the United States, Britain, Germany, Japan, etc. This overdependence has made these nations act unilaterally in conflict situations without approval of the Security Council of the United Nations. In some situations, they flout the orders of the Security Council not to act unilaterally. The Iraq crisis and the role of the coalition forces, which was molded by the United States and Britain is clearer example. "Rather than seek the global interest of peace and security through stability in Iraq and the Middle East region, the domination oriented members amassed their vast economic, diplomatic and military resources, captured and brazenly subjugated Iraq to an unprecedented condominial regime serving their economic interest under Iraq Reconstruction Programme." (Eke, 2007)

This goes to show that the big powers of the world will only agree to cooperate with the United Nations in relation to collective security as long as it serves their interests. "The larger powers (who, after all, must bear the major burdens of enforcing peace under a collective security system) have never been willing to give an unconditional commitment to carry out the commands of the world organization; they have always reserved for themselves some escape hatch. They have never been willing to set up an international army of any significant strength, under direct control of the League of Nations or the United Nations without any strings attached."

Some scholars see the United Nations Collective Security as one-sided system whereby lesser and medium powers are ignored during aggression. They argue that the United Nations has not completely applied the Principle of Collective Security 
on a universal scale. To them, collective security would be meaningful only if it applied to great as well as lesser powers. Thus these scholars have overly criticized the unrepresentative stature of the Security Council. They question the non inclusion of any African country in the membership of the UN Security Council considering the fact that Africa makes about one third membership of the U.N. The lack of geographical spread of members of the Security Council, no doubt, has a negative effect on the function and strength of the Council on the role of maintenance of global peace and security. The major issue here is that such members that feel their voices are only heard but of no policy consequence in protecting their interest feel withdrawn in U.N. actions of Collective Security. According to George Schwarzenberger, "Collective Security as understood at Dumbarton Oaks and San Francisco meant collective security against danger to peace from the middle powers and small states and collective insecurity in the face of aggression by any of the world powers."

The above observation is corroborated by Inis Claude who asserts that "in the final analysis, the San Francisco Conference must be described as having repudiated the doctrine of Collective Security as the foundation for a general, universally applicable system for the management of power in international relations. The doctrine was given ideological lip service, and a scheme was contrived for making it effective in cases of relatively minor importance. But the new organization reflected the conviction that the concept of Collective Security has no realistic relevance to the problems posed by conflict among the major powers (Claude, 1962).

On the other hand, the concerted action of the United Nations in the Korean Crisis of the 1950 proved that Collective Security under the United Nations was possible. The enforcement action undertaken by the United Nations against North Korea that invaded South Korea in 1950 marks the first time the organized community of nations in accordance with the principles of Collective Security, has employed armed forces against an aggressor.

When the United Nations found out that North Korea exhibited aggression against South Korea, it called upon members of the United Nations to send troops and other assistance to South Korea and it asked the United States President to designate a Supreme Commander of the UN Forces. Thus the United Nations demonstrated that even though it had no armed forces at its disposal, as provided for in Article 43 of the Charter, it was not impotent in the face of open aggression.

But critics argued that the enforcement of UN action against North Korea was possible only because the Soviet delegate at the time was boycotting the meetings 
of the Security Council. They argued that had he been present, he presumably would have vetoed any action against North Korea. To them, the action of the United States and of other United Nations members who supported enforcement actions does not necessarily reflect a commitment to resist aggression simply out of belief that the Principle of Collective Security deserved support. One of such critics is Arnold Wolfers who submitted that "instead of being a case of nations fighting any aggressor anywhere and for no other purpose than to punish aggression and to deter potential aggressors, intervention in Korea was an act of collective military defense against the recognized number-one enemy of the United States and of all countries which associated themselves with its action." (Wolfers, 1962)

These critics believed that, had South Korea been the aggressor, it seems unlikely that the non-communist states in the United Nations would have endorsed enforcement action for the benefit of the communist regime in North Korea.

\section{Conclusion}

Collective Security as an institutionalized mechanism for the maintenance of international peace and security has reduced tensions among states in the international community. It has done much by providing the framework for keeping conflicts from becoming major threats to international peace. As Palmer and Perkings pointed out, for Collective Security to be effective, it must be strong enough to cope with aggression from any power or combination of powers, and it must be invoked if and as aggression occurs.

The direction of the United Nations Collective Security system has always been dictated by the world big powers especially the five permanent members of the UN Security Council. Small and medium powers feel left out in the Collective Security arrangement as they can only benefit from the system only when the interests of any of the "big gives" especially the United States are at stake.

However, its weakness does not dismiss the system as wholly unuseful. The UN Collective Security system remains relevant and needed, but its radical defects must be attended to by admitting the added duty to prevent the spread of weapons of mass destruction and terrorism, which were not initially conceived and by enlarging the Security Council to take care of political interests of states perceived as orchestrating these new security challenges "since collective security system has always remained an idealistic concept which has never been defined by treaty and, therefore, can be hijacked by the powerful nations in the lopsided United Nations Security Council. 
It is of great importance therefore, to harp on the need to institute a confidencebuilding measure among the members of the United Nations so as to establish the requisite solidarity and cooperation for enduring global peace and security. To do this is to start genuine reforms as currently canvassed by member states of the United Nations; especially those of them from Asia, Latin America and Africa with enlargement and representation of the Security Council based on geographical location and power-relations.

\section{References and Notes}

Aja, A. (2007) "Peace and Conflict Resolution”, Enugu: Kery and Brothers Ent. (Nig.) Arnold, W. (1962) Discord and Collaboration". Baltimore: John Hopkins

Chaturvedi, A. K. (2006) "Dictionary of Political Science". New Delhi: Academic Publishers.

Dyke, V. N. (1957) "International Politics". New York: Meredith Corporation

Eke, O. (2007) "Strategic Studies: Logical Focus in the $21^{\text {st }}$ Century". Abakaliki: WillyRose and Appleseed Publishing Coy.

Inis, L. C. Jr. (1962) Power and International Relations. New York: Random House

Jones, W. S. (1985) The Logic of International Relations ( $5^{\text {th }}$ ed.) Boston: Little, Brown and Company

Kegley, W. C. (2007) World Politics: Trends and Transformation. California: Thompson Higher Education

Mingst, K. (1999) Essentials of International Relations. New York: W. W. Norton \& Company

Norman, P. and Howard, P. (2007) International Relations. New Delhi: Vivender Kumar Arya

Rostow, E. V. (1968) Law, Power and the Pursuit of Peace. New York: John Wiley \& Sons.

Rourke, J. and Boyer, M. (1998) World Politics: International Politics on the World Stage, Brief. U.S.A.: Dushkin/McGraw Hill

Schwarzenberger, G. (1964) Power Politics: A Study of International Society ( $3^{\text {rd }}$ ed.) London 


\title{
Summary
}

\section{The Failure Of Collective Security In The Post World Wars I And II International System}

\author{
Joseph C. Ebegbulem \\ University of Calabar, Nigeria
}

The League of Nations and the United Nations Organization were two post-World War (World War I and World War II) organizations established for the maintenance of peace and security in the international system. One of the cardinal objectives of these organizations was the promotion of a Collective Security System which was considered as vital in the pursuit of global peace and security. In other words, Collective Security is an institutional mechanism established to address a comprehensive list of major threats to peace and security around the world. With the escalation of conflicts and wars in different parts of the world, there is therefore the need for collective responses at global, regional and national levels in conflict situations. The achievement of collective security in the international system would be based on the principle that any attack on any member of the United Nations would be considered as an attack on all the members.

After a panoramic discourse of the meaning and nature of Collective Security, the paper also examines the problems of collective security in the international system; its failure under the League of Nations and the United Nations. The paper concludes that the weaknesses inherent in the system do not make it unuseful as it is a relevant factor in the maintenance of international peace and security.

Key words: League of Nations, United Nations Organization, Collective Security system , international system, international peace and security, global peace, conflict situations. 